\title{
MANAJEMEN LIMBAH B3 RUMAH TANGGA
}

\author{
Oleh
}

\section{ELI FADILAH}

\section{Latar Belakang}

Meningkatnya volume limbah B3 dan penggunaan di semua sektor kehidupan berakibat kerugian bagi kesehatan manusia serta kerusakan lingkungan, seperti pencemaran udara, tanah, air, dan pencemaran laut.(Yuda, 2021)

Sampah rumah tangga adalah sampah yang berasal dari kegiatan sehari-hari dalam rumah tangga. Sampah Bahan Berbahaya dan Beracun (B3) rumah tangga merupakan sampah bahan berbahaya dan beracun yang dihasilkan oleh kegiatan atau aktivitas sehari-hari di lingkungan rumah tangga atau domestik yang mengandung bahan atau kemasan suatu jenis bahan berbahaya dan atau beracun yang sangat berbahaya untuk lingkungan.(Iswanto et al., 2016) Jenis limbah B3 rumah tangga tidak bernilai ekonomis seperti limbah B3 yang bersifat infeksius misalnya pembalut wanita, perban habis pakai, pestisida dan obatobatan kedaluarsa.(Hesti, 2020)

Karakterisitk limbah B3 rumah Tangga:

a. Mudah terbakar/ meledak, seperti Oli bekas, kaleng bekas pengharum ruangan

b. Korosif, diantaranya pembersih toilet/ kamar mandi, dan baterai, Minyak rambut, shampo, lampu neon, obat kadaluarsa.

c. Beracun seperti detergen pakaian, kaleng bekas, pestisida (baygon), kosmetik/ produk kecantikan, parfum dan deodorant

Agar pengelolaan B3 tidak mencemari lingkungan hidup dan untuk mencapai derajat keamanan tinggi, maka diperlukan peningkatan upaya pengelolaan B3 dengan baik dan terpadu. Kegiatan pengelolaan sampah rumah tangga yang diamanatkan oleh Undang-Undang Nomor 18 Tahun 2008 bermakna agar seluruh sampah yang timbul dapat dipilah, dikumpulkan, diangkut, diolah, dan diproses pada tempat pemrosesan akhir. Pengelolaan sampah merupakan 
kegiatan sistematis dan berkelanjutan yang meliputi pengurangan dan penanganan sampah. Tiga aktivitas utama kegiatan pengurangan sampah, yaitu pembatasan timbulan sampah, pendauran ulang sampah, dan pemanfaatan kembali sampah yang merupakan perwujudan dari prinsip pengelolaan sampah yang berwawasan lingkungan (reduce, reuse, recycle). Diuraikan lima aktivitas utama penanganan sampah yang meliputi pemilahan, pengumpulan, pengangkutan, pengolahan, dan pemrosesan akhir sampah.

\section{Hasil Kajian}

Volume limbah B3 rumah tangga berkontribusi mencemari lingkungan, baik tanah, air dan udara. Kajian penelitian terkait limbah infeksius di pelayanan kesehatan menunjukkan bahwa Petugas kesehatan sangat rentan terhadap penularan infeksi, karena petugas kesehatan dalam bertugas kontak langsung dengan darah dan cairan tubuh.(Hayat, 2015) Faktor penyebab tersebut diakibatkan karena perilaku petugas kesehatan dalam melakukan tugasnya tidak sesuai dengan praktik dalam pengelolaan limbah.(Hayat, 2012)

Limbah B3 yang tidak ditangani dengan baik akan berdampak pada tercemarnya lingkungan perairan. Kajian penelitian menunjukkan bahwa perairan sungai cibanten memiliki status kualitas air sungai yang tidak layak untuk air minum.(Hayat \& Kurniatillah, 2021) Ditambah dengan adanya pencemaran air di sungai Cidanau mengakibatkan gangguan kesehatan masyarakat.(Hayat, 2020) Pengelolaan limbah B3 yang tidak benar akan berdampak pada peningkatan kasus penyakit menular seperti malaria dan DBD.(Hayat \& Kurniatillah, 2009)

Upaya dilakukan oleh masyarakat khususnya pada wilayah rumah tangga adalah bagaimana pengetahuan dan perilaku pengelolaan limbah B3 dapat merubah perilaku dengan baik.(Hayat, 2012) Upaya-upaya yang dilakukan diantaranya pemerintah melakukan promosi kesehatan dengan memanfaatkan media komunikasi menggunakan media video,(Hayat, 2021) edukasi gerakan peran serta masyarakat diperlukan sebagai upaya partisipasi masyarakat.(Hayat, Nurdiawati, et al., 2021) Termasuk di dalam rumah tangga terdapat dukungan seperti dukungan oang tua sebagai pengambil 
keputusan.(Hayat, Arifiati, et al., 2021) Disamping itu pengawasan, pembinaan secara terus- menerus diupayakan termasuk didalamnya penegakan hukum secara persuasif.(Hayat \& Darusmini, 2021)

\section{Kesimpulan}

Agar pengelolaan B3 tidak mencemari lingkungan hidup dan untuk mencapai derajat keamanan tinggi, maka diperlukan peningkatan upaya pengelolaan B3 dengan baik dan terpadu.

\section{Referensi:}

Hayat, F. (2012). Pengaruh predisposing factor, Enable factor, Reinforcing factor terhadap praktik keselamatan kerja pada tenaga kesehatan dalam pengelolaan limbah medis padat di Puskesmas Wilayah Kota Cilegon tahun 2011. In Unpad Repository. Unpad.

Hayat, F. (2015). Analisis faktor pengelolaan limbah medis padat di Rumah Sakit Umum Daerah Kota Cilegon. Faletehan Health Journal, 3, 146-151.

Hayat, F. (2020). Analisis Kadar Klor Bebas (Cl2) dan Dampaknya Terhadap Kesehatan Masyarakat di Sepanjang Sungai Cidanau Kota Cilegon. Jurnal Kesehatan Masyarakat Mulawarman (JKMM), 2(2), 64-69.

Hayat, F. (2021). THE EFFECT OF EDUCATION USING VIDEO ANIMATION ON ELEMENTARY SCHOOL IN HAND WASHING SKILL. Acitya: Journal of Teaching and Education, 3(1), 44-53.

Hayat, F., Arifiati, N., \& Permatasari, T. A. E. (2021). Peran Dukungan Suami dan Faktor Lainnya terhadap Pemanfaatan Pelayanan Gizi oleh Ibu Hamil dengan Risiko Kurang Energi Kronis (KEK). Jurnal Keperawatan Silampari, 5(1), 125-133.

Hayat, F., \& Darusmini, D. (2021). ANALISIS FAKTOR PENGGUNAAN FORMALIN PADA PEDAGANG TAHU DI PASAR TRADISIONAL KOTA SERANG. Jurnal Surya Muda, 3(2), 121-132.

Hayat, F., \& Kurniatillah, N. (2009). Situasi Malaria di Kabupaten Lebak. Kesmas: Jurnal Kesehatan Masyarakat Nasional (National Public Health Journal), 3(6), 259-263. 
Hayat, F., \& Kurniatillah, N. (2021). Microbiological and Water Quality Status of Cibanten River. The First International Conference on Social Science, Humanity, and Public Health (ICOSHIP 2020), 198-200.

Hayat, F., Nurdiawati, E., \& Kurniatillah, N. (2021). EDUKASI GERAKAN PEMBERANTASAN NYAMUK (PSN) DEMAM BERDARAH PADA ANAK USIA SEKOLAH DASAR DI KECAMATAN JAWILAN KABUPATEN SERANG.

Hesti, Y. (2020). Upaya Penanganan Limbah B3 Dan Sampah Rumah Tangga Dalam Mengatasi Pandemi Corona Sesuai Dengan Surat Edaran No. Se. 2/Menlhk/Pslb3/Plb. 3/3/2020tentang Pengelolaan Limbah Infeksius (Limbah B3) Dan Sampah Rumah Tangga Dari Penanganan Corona Virus Disease (Co. Jurnal Pro Justitia, 1(2), 2745-8539.

Iswanto, I., Sudarmadji, S., Wahyuni, E. T., \& Sutomo, A. H. (2016). Timbulan Sampah B3 Rumahtangga Dan Potensi Dampak Kesehatan Lingkungan Di Kabupaten Sleman, YOGYAKARTA (Generation of Household Hazardous Solid Waste and Potential Impacts on Environmental Health in Sleman Regency, YOGYAKARTA). Jurnal Manusia Dan Lingkungan, 23(2), 179188.

Yuda, B. (2021). Pengelolaan Dan Pemanfaatan Limbah B3 (Bahan Berbahaya Dan Beracun) Di Indonesia Pasca Berlakunya Undang-Undang Cipta Kerja \& Peraturan Pelaksanaannya. Universitas Wijaya Putra. 